\title{
Penelitian Klinis
}

\section{SMASH Score as a Predictor off-in Hospital Mortality for Acute Heart Failure Patients}

\author{
Zunaidi Syahputra, Hilfan Ade Putra Lubis, Zainal Safri, Harris Hasan
}

Department of Cardiology and Vascular Medicine, Faculty of Medicine Universitas Sumatera Utara, Haji Adam Malik General Hospital, Medan, Indonesia
Background: The prognosis of AHF patients remain poor. The aim of this study is to design a simple, bedside clinical prognostic scoring model and validate its ability to predict hospital mortality for patients with AHF.

Methods: 255 patients with AHF were enrolled, divided into dead $(n=121)$ and sur$\operatorname{vival}(n=134)$ cohorts. The data were collected from January 2015 to September 2016. Data were collected restropectively. Multivariable analysis was applied to determine independent risk factors and develop the scoring system.

Results: The Multivariate logistic regression analysis, hospital mortality was employed as dependent variable, while age umur $(p=0.0$ I4,OR 4.3 I $4 \mathrm{Cl} 95 \%(\mathrm{I} .346-$ I 3.822)), Diastolic Blood Pressure ( $p=0.00$ I OR 6.2I3 Cl 95\%(2.I2I0-I8.205 )), Systolic Blood Pressure $(p=0.002$ OR $5.043 \mathrm{Cl} 95 \%$ ( I.854-I 3.7I 7)), Heart Rate $(p=0.002$ OR $3.933 \mathrm{Cl} 95 \%(\mathrm{I} .658-9.332))$, haemoglobin $(p=0.044$ OR $2.530 \mathrm{Cl} 95 \%$ (I.026$6.242))$, arrhytmia $(p=0.00$ I OR 7.658 Cl 95\%(2.2 I 7-26.457)), creatinine on admission $(p=0.002$ OR $4.385 \mathrm{Cl} 95 \%$ (I.73I-I I.I04)), QRS duration $(p=0.00$ OR 7.684, Cl $95 \%$ (3.063-19.279)), as independent variables.According to each OR of these variables, we set the new scoring system of hospital mortality for AHF with good calibration by Hosner-lemeshow test $(\mathrm{p}=\mathrm{I})$ and discrimination by AUC $0.925(\mathrm{p}<0.0 \mathrm{I} \mathrm{Cl} 95 \%$ 0.89 I-0.959). The optimal cutt off for prediction mortality was total 6 points, sensitivity $81 \%$ and specificity $89 \%$. We divided the patients with AHF as low risk whom total score $0-3$ points (mortality in hospital 0-2\%), moderate risk whom total score 4-5 points (mortality in hospital 13-46\%), and 6-I2 point as high risk. In the validation cohort indicated that SMASH score as new scoring system was effective with bootstrapping. Conclusion : The SMASH Score is a new scoring system of hospital mortality for AHF can predict with good performance in terms of discrimination, calibration and internally validation.

(Indonesian J Cardiol. 2017;38:207-17)

Keyword: SMASH Score, Acute Heart Failure, Mortality in Hospital 


\title{
SMASH Score Sebagai Prediktor Kematian Kardiovaskular di Rumah Sakit Pada Pasien Gagal Jantung Akut
}

\author{
Zunaidi Syahputra, Hilfan Ade Putra Lubis, Zainal Safri, Harris Hasan
}

Latar Belakang : Prognosis pasien dengan gagal jantung akut ( GJA ) masih buruk, dan stratifikasi resiko mungkin dapat membantu para klinisi dalam penatalaksanaan, dimana pasien yang tergolong buruk, harus dilakukan tindakan agressif dan pemantauan yang ketat. Namun ketersediaan sistem skoring pada GJA masih terbatas. Studi ini bertujuan untuk membuat model skoring prognostik yang sederhana dan validasinya dalam prediksi kematian di rumah sakit pada pasien GJA.

Metode : 255 pasien GJA dibagi 2 kelompok yang mengalami kematian kardiovaskular dan survival di rumah sakit. Data dikumpulkan dari Januari 2015 sampai September 2016. Kriteria inklusi memenuhi panduan GJA berdasarkan ESC guidelines 2016. Dilakukan analisa multivariat dalam mencari faktor resiko yang bebas dan pembuatan sistem skoring.

Hasil : Setelah dilakukan analisa multivariat logistik regressi, kematian di Rumah Sakit sebagai variable bebas, sementara umur ( $\mathrm{p}=0.014, \mathrm{OR}$ 4.314 KI 95\%(1.346-13.822)) Tekanan darah diastolik saat masuk ( $\mathrm{p}=0.001$ OR 6.213 KI 95\%(2.1210-18.205)), tekanan darah sistolik saat masuk ( $\mathrm{p}=0.002$ OR 5.043 KI 95\%( 1.854-13.717)), Denyut nadi( $\mathrm{p}=0.002$ OR 3.933 KI 95\%(1.658-9.332)), hemoglobin $(\mathrm{p}=0.044$ OR 2.530 KI95\%(1.026-6.242)), arritmia ( $\mathrm{p}=0.001$ OR 7.658 KI 95\%(2.217-26.457)), kreatinin masuk ( $\mathrm{p}=0.002$ OR 4.385 KI 95\% (1.731-11.104)), QRS duration ( $\mathrm{p}=0.00$ OR 7.684, KI 95\% (3.063-19.279)) sebagai variabel independen.Berdasarkan masing-masing OR dari variabel ini, diformulasikan sebuah sistem skoring. Sistem skoring yang baru memiliki kalibrasi dan diskriminasi yang sangat memuaskan menurut Hosner-lemeshow test ( $\mathrm{p}=1$ ) dan AUC 0.925 ( $\mathrm{p}<0.01$ CI $95 \%$ 0.891-0.959). Nilai titik potong yang optimal untuk prediksi kematian di rumah sakit adalah 6 poin dengan sensitivitas $81 \%$ and spesifisitas $89 \%$. Kami menggolongkan pasien GJA sebagai resiko kematian rendah dengan total skor 0-3 poins (mortalitas di Rumah sakit 0-2\%), resiko sedang dengan total skor 3-5 points (mortalitas di Rumah Sakit 13-46\%), and 6-14 poin sebagai resiko tinggi. Pada validasi internal bahwa SMASH score sebagai sistem skoring kematian yang baru menunjukan nilai optimisme yang baik secara bootsrapping.

Kesimpulan : SMASH Score adalah sebuah Sistem Skorring baru dalam Prediksi Kematian di Rumah Sakit pada Sindroma Gagal Jantung Akut dengan kalibrasi dan diskriminasi serta validasi yang baik.

(Indonesian J Cardiol. 2017;38:207-17)

Kata kunci: SMASH Score, Gagal jantung akut, kematian kardiovaskular di rumah sakit

Departemen Kardiologi dan Kedokteran Vaskular, Fakultas Kedokteran Universitas Sumatera Utara, Rumah Sakit Umum Haji Adam Malik, Medan, Indonesia.

\section{Correspondence:}

dr. Zunaidi Syahputra, Department of Cardiology and Vascular Medicine, Faculty of Medicine Universitas Sumatera Utara, Haji Adam Malik General Hospital, Medan, Indonesia

E-mail: zunsclub@yahoo.com

\section{Pendahuluan}

Gagal Jantung Akut (GJA) masih merupakan masalah di dunia, angka mortalitas dan morbiditas pada pasien gagal jantung akut masih cukup tinggi. Angka harapan 
hidup pasien gagal jantung masih rendah, 17-45\% dari pasien gagal jantung yang masuk rumah sakit akan mengalami kematian dalam setahun setelah dirawat, dan kebanyakan meninggal dalam 5 tahun kedepan. ${ }^{1,2}$ Prognosisnya terbilang buruk. Studi DOSE- $A H F$ dan Carres- $H F$ membuktikan prognosis buruk pada gagal jantung akut meskipun telah dilakukan terafi optimal. Prevalensi kematian di Rumah Sakit sekitar 10\% dan re-hospitalisasi lebih dari 50\% dalam setahun. ${ }^{3}$ Pada studi prospektif kohort yaitu Acute Decompensated Heart Failure National Registry (ADHERE) Study dan Second EuroHeart Failure Survey (EHFS II) mencatat tingkat kematian dirumah sakit pada pasien gagal jantung akut sebesar $4 \%$ dan $6,7 \%$. 3,4

Gagal Jantung akan menjadi pandemik global, diperkirakan 26 juta orang dewasa didunia menderita gagal jantung, dan ini akan terus bertambah dengan peningkatan usia. Diperkirakan terjadi peningkatan 2 sampai 3 kali lipat pada tahun 2030.5 Studi Epidemiologi memperlihatkan adanya perbedaan kontras karakteristik pasien-pasien gagal jantung pada negara-negara di Asia dengan negara-negara Amerika dan Eropa. Demografi, sosio-kultural, sosio-ekonomi dan fasilitas sangat mempengaruhi perbedaan yang ada. ${ }^{6}$ Masalah penatalaksanaan gagal jantung akut sangat dipengaruhi perbedaan yang ada. Artinya panduan penatalaksanaan gagal jantung akut masih berkiblat pada uji klinis dan evidenced base Eropa dan Amerika, belum ada dengan ruang lingkup Asia. Generalisasi beberapa uji klinik dan aplikasinya menjadi tidak jelas terutama negara-negara Asia. ${ }^{6}$ Hampir semua studi melibatkan populasi negara-negara Eropa, bilapun ada populasi asia relatif kecil dan sangat jarang. Penerapan secara global hasil studi ini akan memberikan respon medikasi yang kurang potensial.

The European Society of Cardiology mengklaim penatalaksanaan gagal jantung akut seperti dengan konsep sindroma koroner akut, dimana konsep time to therapy' dipakai. Konsep 'Time to treatment 'sangat penting pada pasien gagal jantung akut, dimana pada semua pasien gagal jantung akut harus menerima terapi secepat mungkin. Data dari beberapa studi mengindikasikan terapi awal sebagai hal penting dalam penatalaksanaan awal gagal jantung akut. ${ }^{7}$ Salah satu penatalaksanaan awal pasien gagal jantung akut adalah stratifikasi pasien. Stratifikasi pasien sangat penting dalam monitor pasien secara ketat, memilah pasien untuk dilakukan sistem rujukan, penatalaksanaan agresif pasien gagal jantung akut. Sistem stratifikasi yang diharapkan bisa dipakai hampir semua penyelenggara kesehatan dari berbagai strata, menggambarkan sistem yang sederhana yang dapat dikerjakan di beberapa daerah yang fasilitas belum lengkap dan tentu saja mewakili populasi, khususnya Indonesia,dan Asia pada umumnya. ${ }^{7,8}$

Fakta mengungkapkan bahwa hampir $80 \%$ pasien gagal jantung akut yang masuk unit gawat darurat, tidak ditangani oleh kardiolog. ${ }^{9}$ Karakteristik pasien juga berbeda-beda dari segi umur, komorbid, hemodinamik, tampilan klinis dan hasil laboratorium, dimana semuanya dapat mempengaruhi angka kematian pasien gagal jantung akut. ${ }^{10,11,12,13,14,15}$ Studi $A D H E R E$ dan Studi EHFS II memperlihatkan beberapa faktor mem pengaruhi kematian pada pasien gagal jantung akut, antara lain seperti umur, indeks masa tubuh, diabetes mellitus, tekanan darah, kadar elektrolit, fibrilasi atrial, kadar kreatinin dan hemoglobin. Faktor-faktor ini dapat mempengaruhi outcome bila distratifikasi dengan baik. Stratifikasi adalah kebutuhan yang mendesak dalam penatalaksanaan pasien gagal jantung akut. Sistem skoring adalah salah satu bentuk stratifikasi yang mudah untuk diterapkan. Namun Sistem skoring dalam memprediksi kematian dirumah sakit pada pasien gagal jantung akut masih sangat langka terutama yang representatif dengan kondisi demografi Indonesia dan Asia. Untuk itu dibuat sistem skoring baru dalam memprediksi kematian dirumah sakit pada pasien gagal jantung akut. Sistem skoring ini disebut SMASH Score, singkatan dari Scorring system of Mortality in hospital for Acute heart failure Syndromes in Hospitalization.

\section{Metode Penelitian}

\section{Desain Penelitian}

\section{Desain}

Penelitian ini merupakan retrospektif (kohort), yang menguji variabel-variabel tertentu dalam memprediksi kematian kardiovaskular di rumah sakit pada pasienpasien gagal jantung akut. Variabel-variabel yang berpengaruh dirubah kedalam bentuk sistem skoring, lalu dilakukan validasi untuk melihat kemampuan diskriminasi dan kalibrasi sistem skoring yang baru dalam memprediksi kematian kardiovaskular di rumah sakit pada pasien gagal jantung akut.

Penelitian ini dilakukan dengan mengumpulkan data subyek pasien gagal jantung akut yang menjalani perawatan di rumah sakit. Data diambil dari rekam medik pasien gagal jantung akut yang dirawat di 
rumah sakit Haji Adam Malik Medan mulai periode Januari 2015 sampai jumlah sampel sesuai besar sampel terkumpul.

Besar sampel dihitung dengan menggunakan rumus besar sampel untuk uji prognostik, dengan rumus role of thumbs, dimana besar sampel yang mengalami efek positif adalah 10 kali jumlah variabel independen yang sedang diteliti. Besar sampel diperoleh minimal 250 0rang.

\section{Prosedur Penelitian}

Semua sampel dalam penelitian ini adalah pasien dengan diagnosis gagal jantung akut, dengan klasifikasi klinis berdasarkan acuan dari European Society of Cardiology 2016 tentang gagal jantung akut. Peneliti memeriksa rekam medis pasien untuk melihat anamnesis, pemeriksaan fisik, Elektrokardiografi (EKG), Ekokardiografi, pemeriksaan laboratorium saat pasien datang atau masuk ke rumah sakit. Semua rekam medis yang diambil bila memenuhi data yang lengkap dan dibutuhkan. Pemeriksaan Laboratorium dilakukan pada saat pasien masuk rumah sakit melalui Laboratorium Patologi Klinik RS. Haji Adam Malik Medan dengan menggunakan alat Sismex 20. Elektrokardiografi dengan menggunakan alat Bionet Cardiotouch 3000 kecepatan $25 \mathrm{~mm} / \mathrm{s}$ dan skala $10 \mathrm{mV} / \mathrm{mm}$ diperiksa pada saat masuk Unit Gawat Darurat dengan Pemeriksaan ekokardiografi dilaksanakan pada saat di Unit Gawat Darurat dan rawatan intensif dengan alat GE Vivid S6 heart probe $3.25 \mathrm{MHz}$ atau Medison Accuvix 10 dengan sector heart probe $3.50 \mathrm{MHz}$.

Kriteria Inklusi terdiri dari subyek yang didiagnosa dengan gagal jantung akut berdasarkan ESC guidelines acute heart failure 2016 dengan data rekam medik yang lengkap.

Sementara itu pasien gagal jantung akut dengan komorbid malignansi stadium lanjut, syok selain syok kardiogenik, dan data yang tidak lengkap termasuk kriteria ekslusi.

Variabel independen yang mempengaruhi kematian di rumah sakit pada pasien gagal jantung akut diadaptasi dari berbagai studi besar sebelumnya. Adapun variabel-variabel itu adalah umur pasien, jenis kelamin, tekanan darah sistolik dan diastolik, denyut jantung, manifestasi klinis, kadar hemoglobin, Blood Urea Nitrogen (BUN), kadar elektrolit, kadar gula darah, osmolalitas, kreatinin, EKG, ejection fraction, serta faktor resiko pasien.

Data-data yang diperoleh akan dianalisa dengan SPSS 20, sehingga pada akhirnya akan membentuk sistem skoring untuk prediktor kematian di rumah sakit pada pasien gagal jantung akut. Sistem skoring yang terbentuk akan diuji baik menilai kapasitas kalibrasi dan diskriminasi. Validasi interna dilakukan pada sistem skoring.

Perjalanan klinis pasien diperiksa semenjak dari Unit Gawat Darurat (UGD), perawatan diruang intensif dan bangsal sampai pasien pulang atau meninggal di dalam rekam medik, dan dilakukan pencatatan secara sistematis.

\section{Analisis Statistik}

Data numerik dipresentasikan dengan mean + /- standar deviasi atau nilai median, dilakukan perbandingan dengan Student's t-test atau tes Mann Whitney.

Data kategorik ditunjukkan dengan frekuensi dan persentase, dibandingkan dengan Chi-Square test. Analisis Multivariat digunakan regresi logistik dengan metode backward stepwise. Uji kalibrasi dengan menggunakan Hosmer and Lemeshow test. Uji diskriminasi dengan menggunakan Area Under Curved. Selanjutnya transformasi masing-masing variabel ke sistem skoring, perhitungan probabilitas keluaran persamaan logistik, menentukan cutt off point. Validasi sistem skoring.

\section{Hasil Penelitian}

\section{Karakteristik Subyek Penelitian}

Jumlah total subyek penelitian adalah 255 orang, dibagi dalam 2 kelompok yaitu kelompok yang mengalami kematian kardiovaskular di rumah sakit selama perawatan berjumlah 121 orang $(47.5 \%)$ dan yang hidup selama perawatan hingga diizinkan pulang berobat jalan berjumlah 134 orang $(52.5 \%)$.Usia ratarata subyek penelitian adalah 58 tahun, usia tertua 85 tahun dan termuda berusia 16 tahun. 204 orang (80\%) berjenis kelamin laki-laki dan 51 orang (20\%) berjenis kelamin perempuan.

Pasien gagal jantung akut yang dirawat terbanyak dengan subset klinis Oedem Pulmonum/ Acute Lung Oedem (ALO) sebanyak 92 kasus (36.1\%), Acute Decompensated Heart Failurel ADHF sebanyak 78 kasus (30.6\%) dan 68 kasus (26.7\%) dengan syok kardiogenik. Lama rawatan rata 5 sampai 6 hari, dengan masa rawatan terlama 22 hari dan tercepat 1 hari . Penyebab yang mendasari dari gagal jantung akut paling 
banyak disebabkan oleh sindroma koroner akut (SKA) 153 kasus $(60 \%)$, penyakit jantung koroner sebanyak 75 kasus (29.4\%), penyakit jantung hipertensi 17 kasus (6.7\%), penyakit katup jantung sebesar 5 kasus (2\%), penyakit jantung kongenital dan hipertensi masingmasing 2 kasus $(0.8 \%)$, dan 1 kasus $(0.4 \%)$ gagal jantung kanan karena kor pulmonal kronik.

Demografi dan data klinis subyek penelitian, dapat dilihat pada Tabel 1.

\section{Identifikasi Variabel Determinan Kematian Kardiovaskular}

Analisa Bivariat dipakai dalam penetapan variabel mana yang dapat berperan sebagai determinan prognostik kematian kardiovaskular pada pasien gagal jantung akut. Uji Chi-Square digunakan dalam analisa bivariat antar variabel-variabel prognostik. Alasan dipilihnya analisis ini adalah karena semua variabel mempunyai skala pengukuran kategorik. Disamping itu juga disajikan nilai resiko relatif disertai interval kepercayaannya. Analisa bivariat ini yang akan menyeleksi variabel-variabel mana yang akan masuk ke dalam analisa multivariat. Variabel yang pada analisa bivariat dengan nilai $p<0.05$ akan dimasukan ke analisa multivariat selanjutnya. Hasil analisis bivariat dapat dilihat pada Tabel 2.

Dari hasil analisa bivariat diatas maka variabel yang memenuhi syarat untuk masuk kedalam analisis multivariat adalah Umur, Tekanan darah sistolik dan

Tabel 1. Karakteristik Dasar Subyek Penelitian

\begin{tabular}{|c|c|c|c|c|}
\hline \multirow[b]{2}{*}{ Karakteristik } & \multirow{2}{*}{$\begin{array}{l}\text { Seluruh Pasien } \\
\mathrm{n}: 255(100 \%)\end{array}$} & \multicolumn{2}{|c|}{ Kematian di Rumah Sakit } & \multirow[b]{2}{*}{ Nilai $p$} \\
\hline & & $\begin{array}{c}\text { Hidup } \\
\mathrm{n}: 134(52.5 \%)\end{array}$ & $\begin{array}{c}\text { Mati } \\
\text { n: } 121(47.5 \%)\end{array}$ & \\
\hline Umur (rerata),tahun & $58.53 \pm 10.56$ & $57.31 \pm 9.04$ & $59.89 \pm 11.9$ & $0.006^{*}$ \\
\hline \multicolumn{5}{|l|}{ Jenis Kelamin } \\
\hline Pria & $204(80 \%)$ & $112(54.9 \%)$ & $92(45.1 \%)$ & $0.132^{\#}$ \\
\hline Perempuan & $51(20 \%)$ & $22(43.1 \%)$ & $29(56.9 \%)$ & $0.132^{\#}$ \\
\hline \multicolumn{5}{|l|}{ Body Mass Index (BMI) } \\
\hline$\leq 28 \mathrm{~kg} / \mathrm{m} 2$ & $199(78 \%)$ & $99(49.7 \%)$ & $100(50.3 \%)$ & $0.091^{\#}$ \\
\hline$>28 \mathrm{~kg} / \mathrm{m} 2$ & $56(22 \%)$ & $35(62.3 \%)$ & $21(37.5 \%)$ & $0.091^{\#}$ \\
\hline \multicolumn{5}{|l|}{ Klinis } \\
\hline 1.ADHF & $78(30.6 \%)$ & $54(69.2 \%)$ & $24(30.8 \%)$ & $0.000^{\#}$ \\
\hline 2.Hipertensif HF & $15(5.9 \%)$ & $15(100 \%)$ & - & $\mathbf{0 . 0 0 0} \#$ \\
\hline 3.Acute Lung Oedem (ALO) & $92(36.1 \%)$ & $51(55.4 \%)$ & $41(44.6 \%)$ & $0.484^{\#}$ \\
\hline 4.Syok Kardiogenik. & $68(26.7 \%)$ & $13(19.1 \%)$ & $55(80.9 \%)$ & $0.000^{\#}$ \\
\hline 5.High Output Failure & - & - & - & - \\
\hline 6.Right Heart Failure & $2(0.68 \%)$ & $1(50 \%)$ & $1(50 \%)$ & $0.725^{\mathrm{c}}$ \\
\hline Lama Rawatan (hari) & $5.99(1-22)$ & $8.50(1-22)$ & $3.20(1-20)$ & $0.000^{b}$ \\
\hline Tekanan Darah Sistolik (mmHg) & $112.7(50-240)$ & $131.78(60-240)$ & $91.59(50-190)$ & $0.000^{b}$ \\
\hline Tekanan Darah Diastolik (mmHg) & $75.12(40-180)$ & $87.56(50-180)$ & $61.35(40-120)$ & $0.000^{b}$ \\
\hline Heart Rate $(x / i)$ & $108(50-160)$ & $106.55(60-160)$ & $110.86(50-150)$ & $0.000^{b}$ \\
\hline Hemoglobin (g/dL) & $13.69(7.50-18.30)$ & $13.92(7.6-18.30)$ & $13.42(7.50-18.0)$ & $0.004^{b}$ \\
\hline Kadar Urea Nitrogen Darah / BUN (mg/dL) & $133.32(5.04-324)$ & $29.26(5.04-161)$ & $37.82(7.19-324)$ & $0.115^{\mathrm{b}}$ \\
\hline Kadar Gula Darah (mg/dL) & $216.35(60-753)$ & $220.57(71-559)$ & $211.68(60-753)$ & $0.351^{\mathrm{b}}$ \\
\hline Natrium $(\mathrm{mEq} / \mathrm{L})$ & $133.76 \pm 5.618$ & $134.45 \pm 5.0$ & $132.99 \pm 6.12$ & $0.038^{*}$ \\
\hline Kalium (mEq/L) & $4.31(2-6.60)$ & $4.14(2.30-6.50)$ & $4.50(2.00-6.60)$ & $0.000^{b}$ \\
\hline Osmolalitas (mOsm/L) & $293(80.84-365.8)$ & $291.35(119-365)$ & $295.74(80.84-365.82)$ & $0.472^{\mathrm{b}}$ \\
\hline Kreatinin $(\mathrm{mg} / \mathrm{dL})$ & $2.4(0.6-14.2)$ & $1.56(0.67-5.25)$ & $3.37(0.60-14.2)$ & $0.000^{b}$ \\
\hline Ejection Fraction (\%) & $34.98(18-68)$ & $36.91(21-68)$ & $32.84(18-64)$ & $0.000^{b}$ \\
\hline Aritmia & $43(16.9 \%)$ & 8(18.6\%) & $35(81.4 \%)$ & $0.000^{b}$ \\
\hline Durasi QRS & $0.098(0.04-0.8)$ & $0.091(0.04-10)$ & $0.104(0.04-0.24)$ & $0.000^{b}$ \\
\hline Faktor Resiko > 2 & $50(19 \%)$ & $26(52 \%)$ & $24(48 \%)$ & $0.931^{\#}$ \\
\hline
\end{tabular}

Keterangan : $p=$ signifikan $<0.05,{ }^{*}=\mathrm{Uji} \mathrm{T}$ tidak berpasangan, $\#=$ Chi-square test, $\mathrm{b}=$ Mann-Whitney test, $\mathrm{c}=$ fisher test, $\mathrm{n}=$ jumlah 
Indonesian Journal Of Cardiology

Tabel 2. Analisa Bivariat antara Variabel Prognostik dengan Kematian

\begin{tabular}{|c|c|c|c|c|c|c|c|}
\hline \multirow[t]{2}{*}{ No } & \multirow[t]{2}{*}{ Variabel } & \multicolumn{2}{|c|}{ Kematian } & \multirow[b]{2}{*}{$p \#$} & \multirow[b]{2}{*}{ OR } & \multicolumn{2}{|c|}{ IK (95\%) } \\
\hline & & $\begin{array}{l}\text { Hidup } \\
\mathrm{N}(\%)\end{array}$ & $\begin{array}{r}\text { Mati } \\
\mathrm{N}(\%) \\
\end{array}$ & & & Min & Maks \\
\hline 1 & $\begin{array}{l}\text { Umur } \\
\quad \geq 70 \text { tahun } \\
<70 \text { tahun }\end{array}$ & $\begin{array}{c}12(30,8) \\
122(56,5)\end{array}$ & $\begin{array}{l}27(69,2) \\
94(43,5)\end{array}$ & 0.003 & $\begin{array}{l}2.92 \\
\text { Reff }\end{array}$ & 1.405 & 6.067 \\
\hline 2 & $\begin{array}{l}\text { Jenis Kelamin } \\
\text { Laki-laki } \\
\text { Perempuan }\end{array}$ & $\begin{array}{l}112(54.9) \\
22(43.1)\end{array}$ & $\begin{array}{l}92(45.1) \\
29(56.9)\end{array}$ & 0.132 & $\begin{array}{l}0.62 \\
\text { Reff }\end{array}$ & 0.336 & 1.157 \\
\hline 3 & $\begin{array}{l}\text { Indeks Masa Tubuh } \\
\leq 28 \\
>28\end{array}$ & $\begin{array}{l}99(49.7) \\
35(62.5)\end{array}$ & $\begin{array}{c}100(50.3) \\
21(37.5)\end{array}$ & 0.091 & $\begin{array}{l}1.68 \\
\text { Reff }\end{array}$ & 0.916 & 3.093 \\
\hline 4 & $\begin{array}{l}\text { Tekanan Darah Diastolik } \\
\leq 60 \mathrm{mmHg} \\
>60 \mathrm{mmHg}\end{array}$ & $\begin{array}{c}16(16.3) \\
118(75.2)\end{array}$ & $\begin{array}{l}82(83.7) \\
39(24.8)\end{array}$ & 0.000 & $\begin{array}{l}15.5 \\
\text { Reff }\end{array}$ & 8.123 & 29.60 \\
\hline 5 & $\begin{array}{l}\text { Tekanan Darah Sistolik } \\
\leq 100 \mathrm{mmHg} \\
>100 \mathrm{mmHg}\end{array}$ & $\begin{array}{c}31(23.5) \\
103(83.7)\end{array}$ & $\begin{array}{c}101(76.5) \\
20(16.3)\end{array}$ & 0.000 & $\begin{array}{l}16.8 \\
\text { Reff }\end{array}$ & 8.976 & 31.36 \\
\hline 6 & $\begin{array}{l}\text { Heart Rate } \\
\quad>100 x / i \\
\leq 100 x / i\end{array}$ & $\begin{array}{l}71(43.3) \\
63(69.2)\end{array}$ & $\begin{array}{l}93(56.7) \\
28(30.8)\end{array}$ & 0.000 & $\begin{array}{l}2.94 \\
\text { Reff }\end{array}$ & 1.714 & 5.067 \\
\hline 7 & $\begin{array}{l}\text { Syok kardiogenik } \\
\text { Ya } \\
\text { Tidak }\end{array}$ & $\begin{array}{c}13(19.1) \\
121(64.7)\end{array}$ & $\begin{array}{l}55(80.9) \\
66(35.3)\end{array}$ & 0.000 & $\begin{array}{l}7.75 \\
\text { Reff }\end{array}$ & 3.950 & 15.23 \\
\hline 8 & $\begin{array}{l}\text { Kadar Hemoglobin } \\
\leq 13 \mathrm{~g} / \mathrm{dL} \\
>13 \mathrm{~g} / \mathrm{dL}\end{array}$ & $\begin{array}{l}36(39.6) \\
98(59.8)\end{array}$ & $\begin{array}{l}55(60.4) \\
66(40.2)\end{array}$ & 0.002 & $\begin{array}{l}2.27 \\
\text { Reff }\end{array}$ & 1.344 & 3.829 \\
\hline 9 & $\begin{array}{l}\text { BUN } \\
\quad \leq 28 \mathrm{mg} / \mathrm{dL} \\
\quad>28 \mathrm{mg} / \mathrm{dL}\end{array}$ & $\begin{array}{l}87(55.8) \\
47(47.5)\end{array}$ & $\begin{array}{l}69(44.2) \\
52(52.5)\end{array}$ & 0.196 & $\begin{array}{l}0.72 \\
\text { Reff }\end{array}$ & 0.432 & 1.188 \\
\hline 10 & $\begin{array}{l}\text { Kadar Gula Darah/KGD } \\
>200 \mathrm{mg} / \mathrm{dl} \\
\leq 200 \mathrm{mg} / \mathrm{dl}\end{array}$ & $\begin{array}{l}66(57.9) \\
68(48.2)\end{array}$ & $\begin{array}{l}48(42.1) \\
73(51.8)\end{array}$ & 0.124 & $\begin{array}{l}0.68 \\
\text { Reff }\end{array}$ & 0.412 & 1.114 \\
\hline 11 & $\begin{array}{l}\text { Kadar Natrium } \\
\leq 125 \mathrm{mEq} / \mathrm{L} \\
>125 \mathrm{mEq} / \mathrm{L}\end{array}$ & $\begin{array}{c}7(31.8) \\
127(54.5)\end{array}$ & $\begin{array}{c}15(68.2) \\
106(45.5)\end{array}$ & 0.042 & $\begin{array}{l}2.57 \\
\text { Reff }\end{array}$ & 1.009 & 6.530 \\
\hline 12 & $\begin{array}{l}\text { Kadar Kalium } \\
\quad \geq 5.5 \mathrm{mEq} / \mathrm{L} \\
\quad<5.5 \mathrm{mE} / \mathrm{L}\end{array}$ & $\begin{array}{c}6(20.7) \\
128(56.6)\end{array}$ & $\begin{array}{l}23(79.3) \\
98(43.4)\end{array}$ & 0.000 & $\begin{array}{l}5.01 \\
\text { Reff }\end{array}$ & 1.963 & 12.769 \\
\hline 13 & $\begin{array}{l}\text { Kadar Osmolalitas } \\
\geq 297 \mathrm{mosm} / \mathrm{L} \\
<297 \mathrm{mosm} / \mathrm{L}\end{array}$ & $\begin{array}{l}86(54.8) \\
48(49.0)\end{array}$ & $\begin{array}{l}71(45.2) \\
50(51.0)\end{array}$ & 0.367 & $\begin{array}{l}0.79 \\
\text { Reff }\end{array}$ & 0.478 & 1.314 \\
\hline 14 & $\begin{array}{l}\text { Kreatinin } \\
\quad \geq 2.5 \mathrm{mg} / \mathrm{dL} \\
<2.5 \mathrm{mg} / \mathrm{dL}\end{array}$ & $\begin{array}{l}16(24.2) \\
118(62.4)\end{array}$ & $\begin{array}{l}50(75.8) \\
71(37.6)\end{array}$ & 0.000 & $\begin{array}{l}5.19 \\
\text { Reff }\end{array}$ & 2.75 & 9.80 \\
\hline 15 & $\begin{array}{l}\text { Ejection Fraction/EF } \\
\quad \leq 30 \% \\
>30 \%\end{array}$ & $\begin{array}{l}40(40.4) \\
94(60.3)\end{array}$ & $\begin{array}{l}59(59.6) \\
62(39.7)\end{array}$ & 0.000 & $\begin{array}{l}\text { 6.41 } \\
\text { Reff }\end{array}$ & 2.836 & 14.48 \\
\hline 16 & $\begin{array}{l}\text { Arritmia } \\
\text { Ya } \\
\text { Tidak }\end{array}$ & $\begin{array}{c}8(18.6) \\
126(59.4)\end{array}$ & $\begin{array}{l}35(81.4) \\
86(40.6)\end{array}$ & 0.000 & $\begin{array}{l}\text { 6.41 } \\
\text { Reff }\end{array}$ & 2.84 & 14.49 \\
\hline 17 & $\begin{array}{l}\text { Durasi QRS } \\
\quad \geq 0.12 \mathrm{~s} \\
\quad<0.12 \mathrm{~s}\end{array}$ & $\begin{array}{c}20(26.3) \\
114(63.7)\end{array}$ & $\begin{array}{l}56(73.7) \\
65(36.3)\end{array}$ & 0.000 & $\begin{array}{l}4.91 \\
\text { Reff }\end{array}$ & 2.71 & 8.89 \\
\hline 18 & $\begin{array}{l}\text { Faktor Resiko } \\
>2 \\
\leq 2\end{array}$ & $\begin{array}{c}26(52) \\
108(52.7)\end{array}$ & $\begin{array}{c}24(48) \\
97(47.3)\end{array}$ & 0.931 & $\begin{array}{c}1.028 \\
\text { Reff }\end{array}$ & 0.554 & 1.908 \\
\hline
\end{tabular}

\# Uji Chi-Square. Reff: pembanding. 
diastolik, denyut jantung/ Heart Rate, presentasi klinis syok kardiogenik, hasil laboratorium berupa kadar hemoglobin, natrium dan kalium, serta kreatinin saat masuk memenuhi syarat masuk analisa multivariat. Sementara itu dari hasil pemeriksaan penunjang durasi QRS dan gambaran aritmia pada elektrokardiografi,fungsi sistolik/ ejection fraction pada pemeriksaan ekokardiografi juga akan diuji analisa multivariat.

\section{Analisis Multivariat dengan Metode Backward Stepwise untuk Memperoleh Model Prognostik.}

Setelah dilakukan analisa bivariat, analisis multivariat dilakukan dalam mendeterminasi variabel-variabel prognostik yang paling mempengaruhi kematian kardiovaskular pada pasien gagal jantung akut sehingga menghasilkan model prognostik. Hasil analisa multivariat dengan metode backward stepwise LR, didapati hasil pada Tabel 3.

\section{Membuat Sistem Skoring untuk Setiap Variabel Model Prognostik Pada SMASH Score}

Dalam membuat sistem skoring dari model prognostik pada hasil analisis multivariat, skoring untuk setiap variabel dapat ditentukan dengan memanfaatkan nilai B dan SE untuk setiap variabel, pada Tabel 4.

Langkah selanjutnya adalah melakukan analisa model skor yang telah dibuat dengan regresi logistik, didapati persamaan regresi (y) yang diperoleh adalah $-4.369+0.847$ (total skor). Model skoring yang didapat dilakukan uji Hosmer dan Lemeshow, didapatkan nilai p 1.000 .

\section{Menghitung Probabilitas Subyek Untuk Mengalami Kematian Kardiovaskular}

Probabilitas subyek penelitian untuk mengalami kematian kardiovaskular dapat dihitung dengan persamaan regresi sebelumnya, yaitu;

$\mathrm{P}=1 / 1+\exp (-\mathrm{y}) \ldots . . \mathrm{y}=-4.369+0.847$ (total skor).

Kemungkinan rentang nilai skor subyek adalah antara 0 sampai 14 . Skor 0 diperoleh apabila subyek sama sekali tidak ada variabel prognostik dan skor 14 diperoleh apabila subyek mempunyai semua variabel prognostik. Hasil perhitungan tersebut dapat dilihat pada Gambar 1.

Tabel 3. Hasil Analisis Multivariat

\begin{tabular}{llccc}
\hline No & Variabel & OR & $95 \% \mathrm{KI}$ & Signifikansi (p) \\
\hline 1 & Umur $\geq 70$ tahun & 4.314 & $1.346-13.832$ & 0.014 \\
2 & TD Diastolik $\leq 60 \mathrm{mmHg}$ & 6.213 & $2.120-18.205$ & 0.001 \\
3 & TD Sistolik $\leq 100 \mathrm{mmHg}$ & 5.043 & $1.844-13.717$ & 0.002 \\
4 & Heart Rate $>100 \mathrm{x} / \mathrm{i}$ & 3.933 & $1.658-9.332$ & 0.002 \\
5 & Hemoglobin $\leq 13 \mathrm{~g} / \mathrm{dL}$ & 2.530 & $1.026-6.242$ & 0.044 \\
6 & Kreatinin $\geq 2.5 \mathrm{mg} / \mathrm{dL}$ & 4.385 & $1.731-11.104$ & 0.002 \\
7 & Arritmia $(+)$ & 7.658 & $2.217-26.457$ & 0.001 \\
8 & Durasi QRS EKG $\geq 0.12 \mathrm{~s}$ & 7.684 & $3.063-19.279$ & 0.000 \\
\hline
\end{tabular}

$\mathrm{OR}=$ odds ratio, $\mathrm{KI}=$ koefiden Interval

Tabel 4. Konversi Variabel Model Prognostik ke Model Skoring

\begin{tabular}{llccccc}
\hline No & Variabel & B & SE & B/SE & (B/SE)/2.013 & Skor \\
\hline 1 & Umur $\geq 70$ tahun & 1.462 & 0.594 & 2.461 & 1.222 & 1 \\
2 & TD Diastolik $\leq 60 \mathrm{mmHg}$ & 1.827 & 0.549 & 3.327 & 1.652 & 2 \\
3 & TD Sistolik $\leq 100 \mathrm{mmHg}$ & 1.618 & 0.511 & 3.166 & 1.572 & 2 \\
4 & Heart Rate $>100 \mathrm{x} / \mathrm{i}$ & 1.369 & 0.441 & 3.104 & 1.541 & 2 \\
5 & Hemoglobin $\leq 13 \mathrm{~g} / \mathrm{dL}$ & 0.928 & 0.461 & 2.013 & 1.000 & 1 \\
6 & Kreatinin $\geq 2.5 \mathrm{mg} / \mathrm{dL}$ & 1.478 & 0.474 & 3.118 & 1.548 & 2 \\
7 & Arritmia $(+)$ & 2.036 & 0.633 & 3.216 & 1.59 & 2 \\
8 & Durasi QRS EKG $\geq 0.12 \mathrm{~s}$ & 2.039 & 0.469 & 4.347 & 2.159 & 2 \\
\hline
\end{tabular}




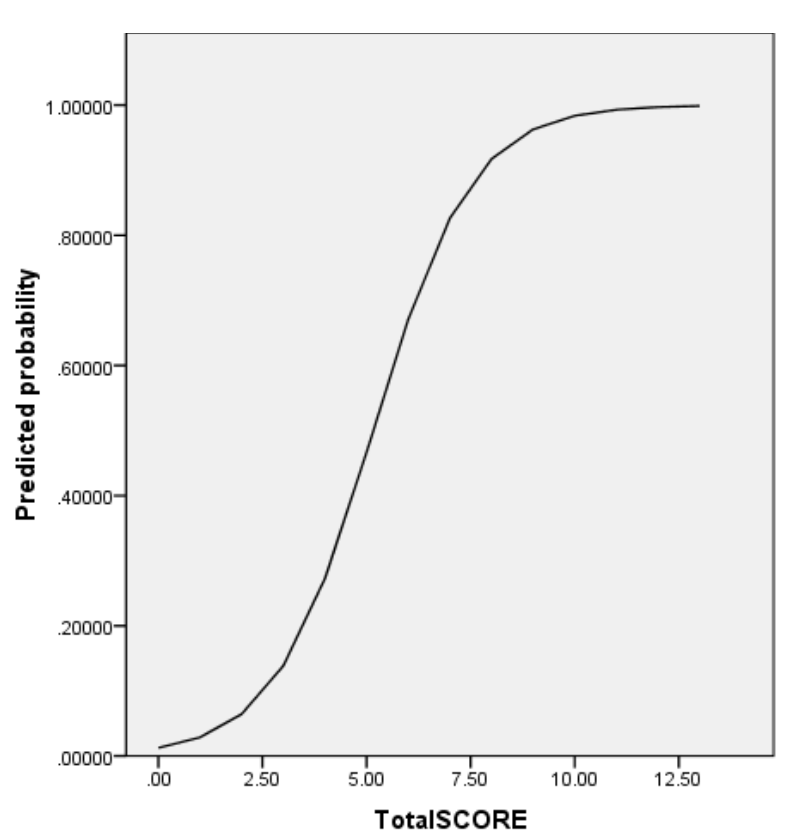

Gambar 1. Grafik hubungan antara jumlah skor yang diperoleh dengan kemungkinan kejadian kematian dirumah sakit.

\section{Menetapkan Titik potong Sistem Skoring SMASH Score}

Titik potong dapat dilakukan dengan mengukur sensitivitas dan spesifitas secara statistik titik potong dapat dilihat pada Gambar 2.
Titik potong dapat dijumpai pada skor 6. Artinya apabila skor subyek lebih dari atau sama dengan 6, subyek akan mempunyai prognosis yang buruk.

\section{Membuat Kartu Skoring pada SMASH Score}

Untuk memudahkan aplikasi Smash Score ini maka dibuatkan sebuah kartu skoring sehingga dapat memantau pasien gagal jantung akut. Kartu skoring dapat dilihat pada Tabel 5.

\section{Validasi Internal SMASH Score}

Untuk menguji apakah persamaan SMASH Score dapat digunakan di populasi dengan karakteristik yang sama dalam jumlah yang lebih besar, maka dilakukan validasi internal dengan bootsrapping. Bootstrapping dilaksanakan dengan bantuan Aplikasi IBM SPSS Bootstrapping 20. Data diambil dari kumpulan kumpulan subyek penelitian pada $S M A S H$ Score namun data subyek yang sudah terambil akan dikembalikan lagi dan diacak untuk diambil lagi, sampai keseluruhan subyek yang diambil mencapai 1000 sampel baru.

Setelah dilakukan dengan metode bootstrapping, ternyata hanya sedikit perubahan nilai $p$. Pada pengujian persamaan sistem SMASH Score sebelumnya $p=0.000$. Pada pengujian secara bootstrapping dengan 1000 sampel diperoleh nilai $p$ 0.001. Dapat dikatakan

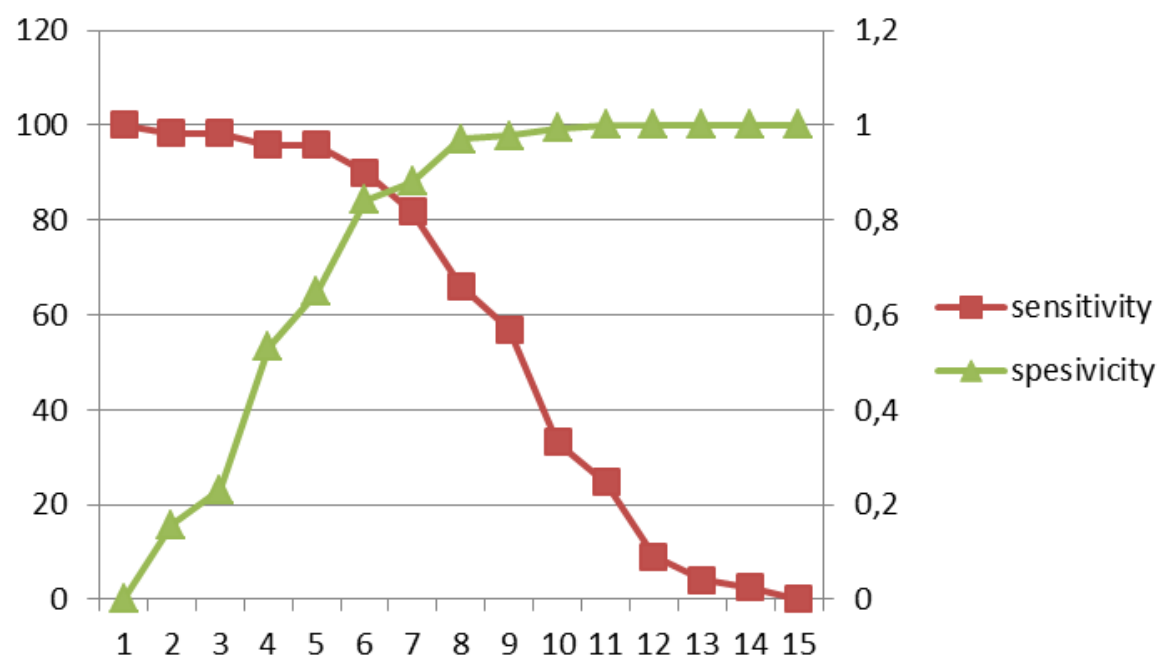

Gambar 2. Grafik titik potong nilai skor dengan kematian kardiovaskular di rumah sakit. 
bahwa SMASH Score dapat diaplikasikan pada populasi berkarakteristik sama dengan jumlah sampel yang lebih besar. stratifikasi pasien gagal jantung akut, aplikasinya juga dapat dilakukan pada semua lini pelayanan kesehatan karena variabel yang dipakai sangat sederhana dan rutin

Tabel 5. Kartu Skoring pada SMASH Score

\begin{tabular}{|c|c|c|c|c|}
\hline \multicolumn{5}{|c|}{ SMASH Score Monitoring Card for AHF Patients } \\
\hline Variabel & Ya & Tidak & Probabilitas & Penatalaksanaan \\
\hline Umur Pasien $\geq 70$ tahun & 1 & 0 & $\begin{array}{c}\text { Low Risk } \\
\text { (Total Skor 0-2) }\end{array}$ & \\
\hline TD Diastolik $\leq 60 \mathrm{mmHg}$ & 2 & 0 & Mortalitas1-6\% & \\
\hline TD Sistolik $\leq 100 \mathrm{mmHg}$ & 2 & 0 & Moderate Risk & \\
\hline Heart Rate $>100 \mathrm{x} / \mathrm{i}$ & 2 & 0 & (Total Skor 3-5) & \\
\hline & & & Mortalitas 13-46\% & \\
\hline $\mathrm{Hb}$ saat masuk $\leq 13 \mathrm{~g} / \mathrm{dL}$ & 1 & 0 & High Risk & \\
\hline Kreatinin masuk $\geq 2.5 \mathrm{mg} / \mathrm{dl}$ & 2 & 0 & (Total Skor 6-14) & \\
\hline Arritmia & 2 & 0 & Mortalitas 67-99\% & \\
\hline Durasi QRS EKG $\geq 0.12 \mathrm{~s}$ & 2 & 0 & & \\
\hline Total Skor & & & & \\
\hline
\end{tabular}

\section{Diskusi}

Pasien gagal jantung akut pada penelitian ini lebih banyak disebabkan oleh sindroma koroner akut, ini relevan dengan beberapa studi besar yang salah satunya adalah studi OPTIMIZE-HF. Disamping itu sindroma koroner akut masih menjadi kasus kardiovaskular yang sering terjadi di seluruh dunia. Angka kematian pada penelitian ini cukup tinggi dibanding pada penelitian-penelitian dunia lainnya, yang membahas studi epidemiologi tentang gagal jantung akut. Insiden kematian dirumah sakit pada pasien gagal jantung akut ditemukan rendah pada studi-studi FINNAKVA (7.1\%), ADHERE (4.0\%), EHFS II (6.7\%) dan OPTIMIZE-HF (3.8\%) serta $12.7 \%$ pada studi AHEAD. Perbedaan yang kontras ini didasarkan pada perbedaan karakteristik populasi dan presentasi syok kardiogenik juga relatif rendah pada studi besar diatas. Syok kardiogenik didiagnosa hanya $4 \%$ pada populasi EHFS II, $2.3 \%$ pada FIN-AKVA, $11.7 \%$ pada ALARM$H F$ dan $14.7 \%$ pada studi $A H E A D$. Dilain pihak, penelitian studi lain menunjukan populasi yang lebih muda, pria, lebih sedikit komorbid.

Pasien gagal jantung akut mempunyai prognosa yang buruk sehingga diperlukan suatu sistem acuan dalam penatalaksanaannya. Sistem skoring dapat membantu dalam stratifikasi pasien gagal jantung akut dan aplikasi klinisnya juga mudah. SMASH Score merupakan modalitas yang dapat digunakan dalam dikerjakan pada semua sistem pelayanan kesehatan. Dari presentasi klinis meliputi tekanan darah sistolik dan diastolik, frekuensi jantung (heart rate) dan umur, sementara itu dari pemeriksaan laboratorium terdiri dari hemoglobin dan kreatinin serta dari hasil elektrokardiografi. Sebagian besar faktor-faktor yang masuk dalam SMASH Score telah dilaporkan pada penelitian-penelitian besar, dapat sebagai prediktor kuat kematian kardiovaskular dirumah sakit. Bila ditinjau dari studi $A D H E R E$ yang mengembangkan prediktor paling mempengaruhi kematian dirumah sakit pada pasien gagal jantung akut terdiri dari kadar urea nitrogen dalam darah, tekanan darah sistolik dan kadar kreatinin saat masuk, SMASH Score juga memberikan prediktor yang sama, kecuali Kadar urea nitrogen dalam darah. Kreatinin dan kadar urea nitrogen dalam darah erat kaitannya pada perburukan fungsi ginjal atau sistem kardio renal. Fillipatos dkk mengatakan kadar urea nitrogen dalam darah lebih kuat sebagai prediktor perburukan pada pasien gagal jantung akut, bila hanya keduanya dibandingkan. Namun Weinfeld dkk dan Forman dkk, membuktikan bahwa serum kreatinin lebih baik dan menjadi patokan perburukan fungsi ginjal pada pasien gagal jantung akut. Disamping itu serum kreatinin juga lebih murah dan tersedia pada seluruh rumah sakit. Kematian kardiovaskular dengan gagal jantung akut hipertensif relatif rendah, pada penelitian ini juga memberikan gambaran yang sama. 
Kemampuan Kalibrasi SMASH Score tergolong baik dengan melihat hasil uji hosmer-lemeshow $\mathrm{p}>0.05$ dan kemampuan diskriminasi dengan hasil Area Under the Curved sebesar 0.925. Sehingga SMASH Score sebagai perangkat prognostik telah memenuhi syarat. Walaupun demikian, studi prospektif dengan sampel yang besar masih diperlukan dalam mempertegas effikasi dari sistem skoring ini.

SMASH Score merupakan sistem skoring sangat sederhana dan mudah. SMASH Score adalah sistem yang baru sehingga diperlukan validasi sistem. Hal ini sangat mempengaruhi hasil outcome. Validasi Internal penelitian ini menggunakan sistem bootstrapping untuk mengatasi pengaruh kebetulan sampel. Steyerberg dkk, menyatakan bootstrapping merupakan validasi internal terbaik pada model regresi logistik. Validasi SMASH Score memberikan hasil yang baik, sehingga dapat diaplikasikan. SMASH Score belum dilakukan validasi secara eksterna, untuk itu perlu dilakukan penelitian lebih lanjut dengan melibatkan subyek dari karakteristik, geografi ataupun waktu.

\section{Kesimpulan}

SMASH Score merupakan sistem skoring yang dapat memprediksi kematian kardiovaskular di rumah sakit pada pasien gagal jantung akut dengan kemampuan kalibrasi, diskriminasi dan validasi interna yang baik.

\section{Daftar Singkatan}

AHEAD: Acute Heart Failure Database

ADHERE: Acute Decompensated Heart Failure National Registry

ADHF: Acute Decompensated Heart Failure

ADCHF: Acute Decompensated Chronic Heart Failure

AHF: Acute Heart Failure

BUN: Blood Urea Nitrogen

CRT: Cardiac Resynchronization Therapy

CVP: Central Venous Pressure

DM: Diabetes Mellitus

EFFECT: Enhanced Feedback for Effective Cardiac treatment.

EHFS: EuroHeart Failure Survey

EKG: Elektrokardiografi

ESC: European Society Cardiology

ESCAPE:Evaluation study of congestive heart failure and Pulmonary artery Catheterization effectiveness GJA: Gagal Jantung Akut

ICD: Implantable Cardioverter-defibrillator

OPTIMIZE-HF: Organizing Program to initiate lifesaving treatment in hospitalized patients with Heart Failure

SMASH: Scorring system Mortality in hospital for Acute heart failure Syndromes in hospitalization.

BMI: Body Mass Index

EKG: Elektrokardiogram

HR: Heart Rate/Denyut Jantung

UGD: Unit Gawat Darurat

\section{Persetujuan Etik}

Persetujuan Komisi Etik tentang pelaksanaan penelitian kesehatan NO :54/TGL/KEPK FK USU-RSUP HAM/2017

\section{Persetujuan untuk Publikasi}

Semua pihak sudah menyetujui publikasi naskah ini.

\section{Konflik kepentingan}

Tidak ada konflik kepentingan dalam penelitian ini.

\section{Pendanaan}

Pendanaan penelitian ini berasal dari Departemen Kardiologi dan Kedokteran Vaskular Fakultas Kedokteran Universitas Sumatera Utara.

\section{Daftar Pustaka}

1. Ponikowski P, Voors AA, Anker SD, et al. 2016 ESC Guidelines for the diagnosis and treatment of acute and chronic heart failure:the task force for diagnosis and treatment of acute and chronic heart failure of the European Society of Cardiology. European Heart Journal 2016. doi: 10.109/eurheartj/chw128

2. Abraham WT, Fonarow GC, Albert NM et al. Predictors of in-hospital mortality in patients hospitalized for heart failure: insights from the Organized Program to Initiate Lifesaving Treatment in Hospitalized with heart failure (OPTIMIZEHF). J Am Coll Cardiol 2008;52:347-356. Doi: 10.1016/j. jacc.2008.04.028.

3. Nieminen MS, Brutsaert D, Dickstein K, et al, EuroHeart Survey Investigators, Heart Failure Association, European Society of Cardiology: EuroHeart Failure Survey II (EHFS II); 


\section{Syahputra Z et al: SMASH Score as a Predictor off-in Hospital Mortality for Acute Heart Failure Patients}

a survey on hospitalized acute heart failure patients:description of population. Eur Heart J 2006,27:2725-2736.

4. Spinar J, Parenica J, Vitovec J et al. Baseline characteristics and hospital mortality in the Acute Heart Failure Database (AHEAD) Main registry.Spinar et al. Critical Care 2011,15:R291.

5. Ponikowski P, Jankowska EA. Pathogenesis and clinical presentation of Acute Heart Failure. Rev Esp Cardiol (Engl Ed) 2015;68:331-337.

6. Mentz RJ, Roessig L, Greenberg BH et al, Heart Failure Clinical Trials in East and Southeast Asia:understanding the importance and defining the next steps. J Am Coll Cardiol HF 2016;4:41927.

7. Mebazaa A, Yilmaz MB, Levy P et al. Recommendations on pre-hospital \& early hospital management of acute heart failure: a consensus paper fom the Heart Failure Association of the European Society of Cardiology, the European Society of Emergency Medicine and the Society of Academic Emergency Medicine. European journal of Heart Failure 2015, 17,544-558. doi 10.1002/ejhf.289.

8. Marteles MS, Gracia JR, Lopez IG. Pathophysiology of acute heart failure: A world to know. Rev Clin Esp 2015.doi: 10.1016/j. rce.2015.09.010

9. Gheorghiade M, Abraham WT, Albert NM et al. Systolic Blood Pressure at Admission, Clinical Characteristics, and Outcomes in Patients Hospitalized With Acute Heart Failure. JAMA 2006;296:2217-2226.

10. Follath F, Delgado JF, Mebazza A et al. Classifying patients with acute heart failure presentation, treatment and outcome. A nine country survey of acute heart failure management (ALARMHF). Eur J Heart Fail 2008.7(suppl):64.

11. Jumean MF, Kierman MS. Determinants of survival following hospitalization for acute heart failure. Curr Heart Fail Rep 2014;11:201-211.

12. Kaneko H, Suzuki S, Goto M et al. Incidence and Predictors of Rehospitalization of Acute Heart Failure Patients. Int Heart J. 2015;56:219-225
13. Kajimoto K, Minami Y, Sato N et al. Etiology of Heart Failure and Outcomes in Patients Hospitalized for Acute Decompensated Heart Failure With Preserved or Reduced Ejection Fraction.Am.J Cardiol 2016;s0002-9149(16)31496-5.doi:10.1016/j. amjcard.2016.08.080.

14. Latado AL, Passos LC, Braga JC et al. Predictors of In-hospital Lethality in Patients With Advanced Heart Failure. Arquivos Brasileiros de Cardiologia, 2006 Volume 87 No 2.

15. McMurray JJ, Adamopoulos S, Anker SD et al. ESC guidelines for the diagnosis and treatment of acute and chronicheart failure 2012: the Task Force for the Diagnosis and Treatment ofAcute and Chronic Heart Failure 2012 of the European Society ofCardiology. Developed in collaboration with the Heart. Eur Heart 2012;33:1787e1847.

16. O'Connor CM, Hasselblad V, Mehta RA et al. Predictors of mortality after discharge in patients hospitalized with heart failure: an analysis from the organized Program to Initiate Lifesaving Treatment in Hospitalized Patients with Heart Failure (OPTIME-HF). Am Heart J 2008;156:662-673. Doi 10.1016/j. jahj.2008.04.030.

17. Ouwerkek W, Voors AA, Zwinderman AH et al. Factors Influencing the Predictive Power of Models for Predicting Mortality and/or Heart Failure Hospitalization in Patients With Heart Failure. JACC Heart Failure 2014.doi:10.1016/j. jchf.2014.04.006

18. Sliwa K, Davidson BA, Mayosi BM et al. Readmission and death after an acute heart failure event: predictors and outcomes in sub-Saharan Africa:nresults from the THESUS-HF registry. European Heart Journal 2013.doi:10.1093/euheartj/eht.393.

19. Wattad M, Darawsha W, Solomonica A et al. Interaction between worsening renal function and persistent congestion in acute decompensated heart failure. Am J Cardiol. 2015;115:932-7.

20. Zannad F, Mebazza A, Juilliere Y et al. Clinical profile, contemporymanagement and one year mortality in patients with severe acute heart failure syndromes: The EFICA Study. Eur J Heart Fail 2006,8:697-705. 